\title{
EXTENTION OF THE CURRENT NORTHERN DISTRIBUTION RANGE OF FRESHWATER MUSSEL DIPLODON CHILENSIS (GRAY, 1828) (BIVALVIA:HYRIIDAE) IN CHILE
}

\author{
EXTENSION DEL LIMITE NORTE DE LA DISTRIBUCION \\ ACTUAL DEL CHORITO DE AGUA DULCE DIPLODON \\ CHILENSIS (GRAY, 1828) (BIVALVIA:HYRIIDAE) EN CHILE
}

\author{
Esperanza Parada ${ }^{1}$, Santiago Peredo ${ }^{1}$, José Valenzuela ${ }^{2} \&$ Daniela Manuschevich ${ }^{3}$ \\ ${ }^{1}$ Escuela de Ciencias Ambientales, Facultad de Recursos Naturales, \\ Universidad Católica de Temuco eparada@uct.cl \\ ${ }^{2}$ Consultora CADE-IDEPE, Santiago \\ ${ }^{3}$ Escuela Ciencias Biológicas, Pontificia Universidad Católica de Chile.
}

\begin{abstract}
The extent of the northern distribution range of Diplodon chilensis is reported herein from specimens collected in the Río Grande, an affluent of the Río Limari located to the south of the village of Carachilla $\left(30^{\circ} 28^{\prime} \mathrm{S} ; 71^{\circ} 05^{\prime} \mathrm{W}\right)$.
\end{abstract}

Diplodon chilensis (Gray 1828) is the most abundant freshwater bivalve in Chile, with the greatest biomass in the country's continental waters. According to Haas (1969), D. chilensis inhabits the entire country. Current reports (Parada \& Peredo 2002, 2006) indicate a D. chilensis distribution range stretching from Río Mataquito, Curicó, Region VII ( $\left.34^{\circ} 58^{\prime} \mathrm{S} ; 71^{\circ} 48^{\prime} \mathrm{W}\right)$ in the north to Río

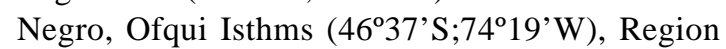
$\mathrm{XI}$, in the south.

According to Parada \& Peredo (op cit.) this distribution ranges matches that of the subspecies D. chilensis chilensis, since at present, D. chilensis patagonicus, the other subspecies described by Haas (op cit.), has not been reported in Chile. The distribution range of the latter subspecies is mainly restricted to the Chilean-Argentinean Patagonia area. According to Bonetto (1973), D. ch. patagonicum is found along the Araucanian Argentinean lakes chain, from Mendoza Province to Lake Futalauquén including the rivers Negro and Neuquén.
The present communication reports the extent of the current northern distribution range of $D$. chilensis in Chile.

In February 2006, 15 specimens of D. chilensis were collected in Río Grande, an affuent of Río Limarí, located to south of the village Carachilla $\left(30^{\circ} 28^{\prime} \mathrm{S}\right.$; $\left.71^{\circ} 05^{\prime} \mathrm{W}\right)$. The specimens were taken from areas with low current, where the muddy substrate, was mixed with boulders ( $18 \mathrm{~cm}$ diameter average).

Specimens were deposited in collection of the Biological Department of the Catholic University of Temuco, Chile.

In the laboratory, valve morphology and biometric characteristics were determined for each specimen including valve length (VL), width (VW) and height (VH); hinge and teeth characteristics, sex determination by gonad smears; and the presence of embryos or larvae in female inner demibranchs. At the population level, the collected specimens were used to determined the size structure and Pearson's correlation analysis between VL and VW and between VL and VH. The individuals collected 
Extention of distribution range of Diplodon chilensis: PARADA, E. ET AL

were also compared to specimens in the collection of the Biological Department of the Catholic University of Temuco, Chile.

The biometric analysis showed a size range of 59.3 to $33.0 \mathrm{~mm} \mathrm{VL}, 28.5$ to $17.7 \mathrm{~mm} \mathrm{VH}$ and 21 and $9.4 \mathrm{~mm}$ VW in the Río Grande specimens. Correlations between VL - HV and VL - WV were highly significant ( Figs.1, 2).

The size range and population size structure matched those registered in other lentic and lotic populations of $D$. chilensis, in central-southern Chile (Parada et al. 1990; Parada \& Peredo 1994) (Fig.3). It should be noted that specimens collected in the present study have very thin and, therefore, weak valves, unlike specimens from the lotic populations in central-southern Chile. These differences can be attributed to water flow and water currents in central-southern as compared to northern-central Chile. The sexual proportion was determined to be $1: 1$.
Only some females were gravid and these had inner demibranchs crowded with gloquidium larvae. No females were recorded with embryos in their demibranches, probably due to collection date (end of summer).

The morphological features of the larvae, especially the shape, size, and position and shape of the larval tooth, coincided with the characteristics described by Parada et al. (1989). Valve analysis, hinge characteristics, and especially the number and type of teeth corresponded to those described by Paradaet al. (1989) for Diplodon chilensis.

This finding supports the extension of the current D. chilensis distribution range and, since the valvular morphologic features correspond to those reported by Haas (1969), the specimens belong to the subspecies Diplodon chilensis chilensis.

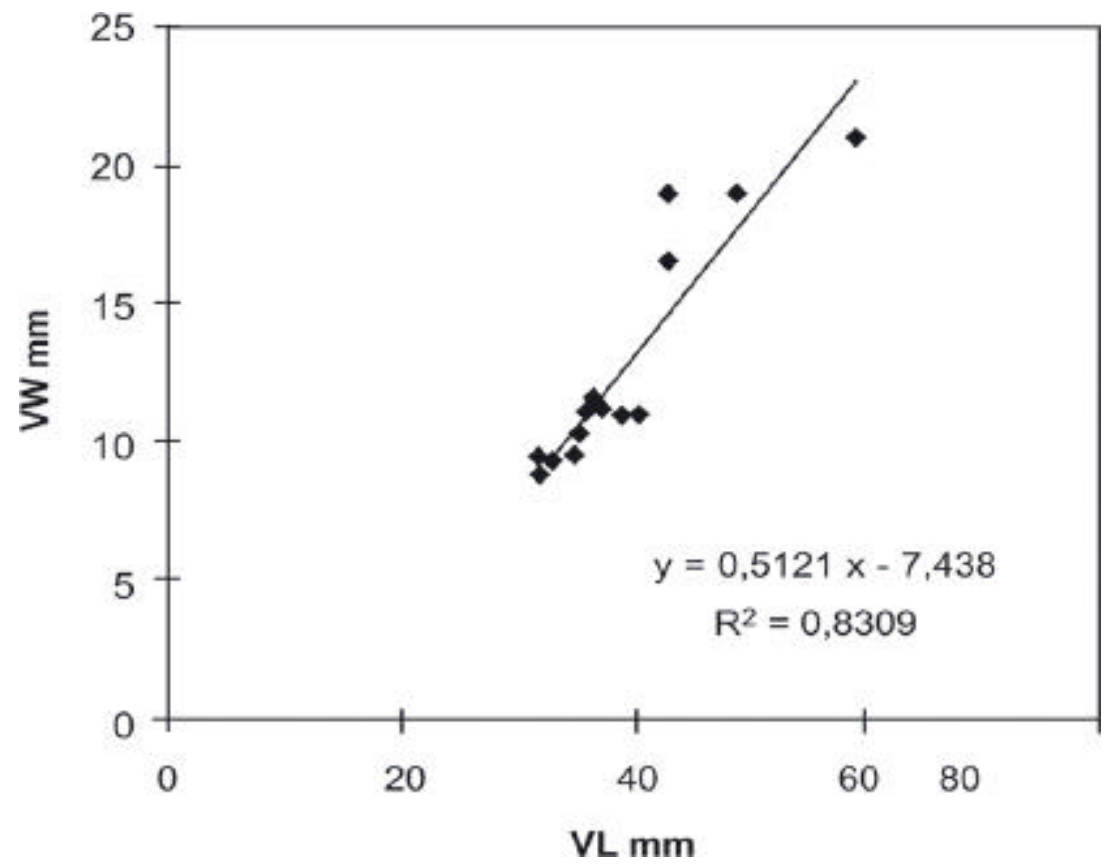

Figure 1: Pearson's correlation between valve length (VL) and valve width (VW) from the Río Grande Diplodon chilensis population $(\mathrm{p}<0.05)$.

Figura 1: Correlación de Pearson entre la longitud valvar y el ancho valvar de la población de Diplodon chilensis de Río Grande $(\mathrm{p}<0,05)$. 


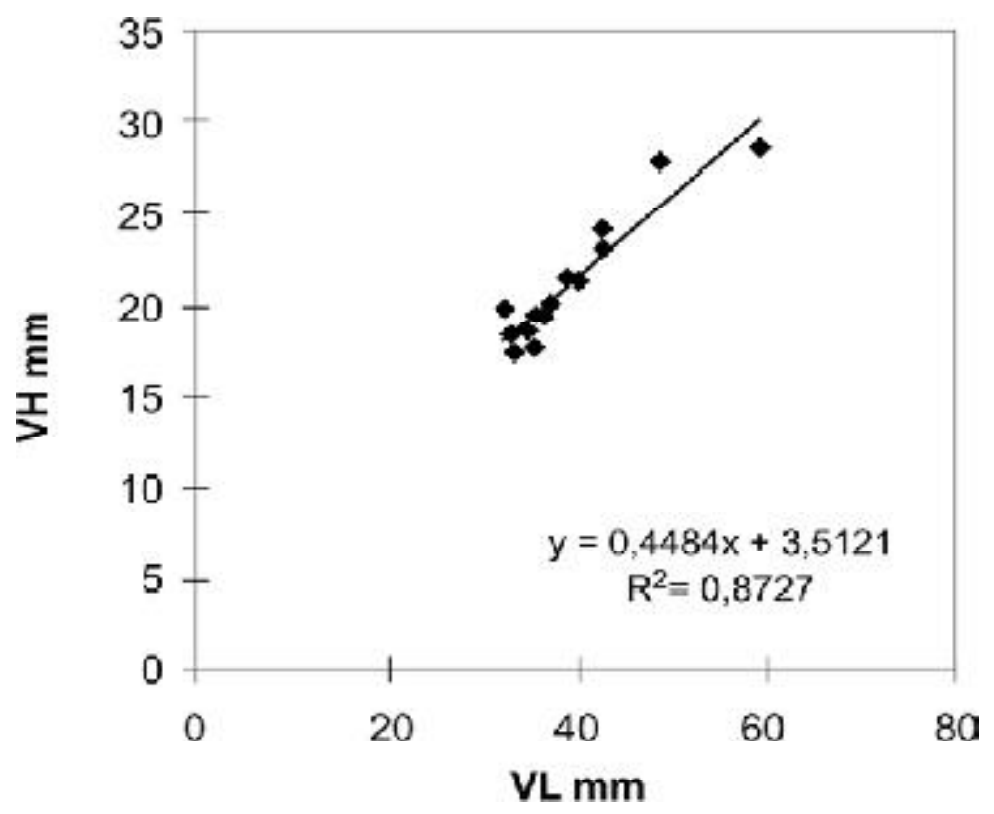

Figure 2: Pearson's correlation between valve length (VL) and valve height (VH) from the Río Grande Diplodon chilensis population $(\mathrm{p}<0.05)$.

Figura 2: Correlación de Pearson entre la longitud valvar y el alto valvar de la población de Diplodon chilensis de Río Grande $(\mathrm{p}<0,05)$.

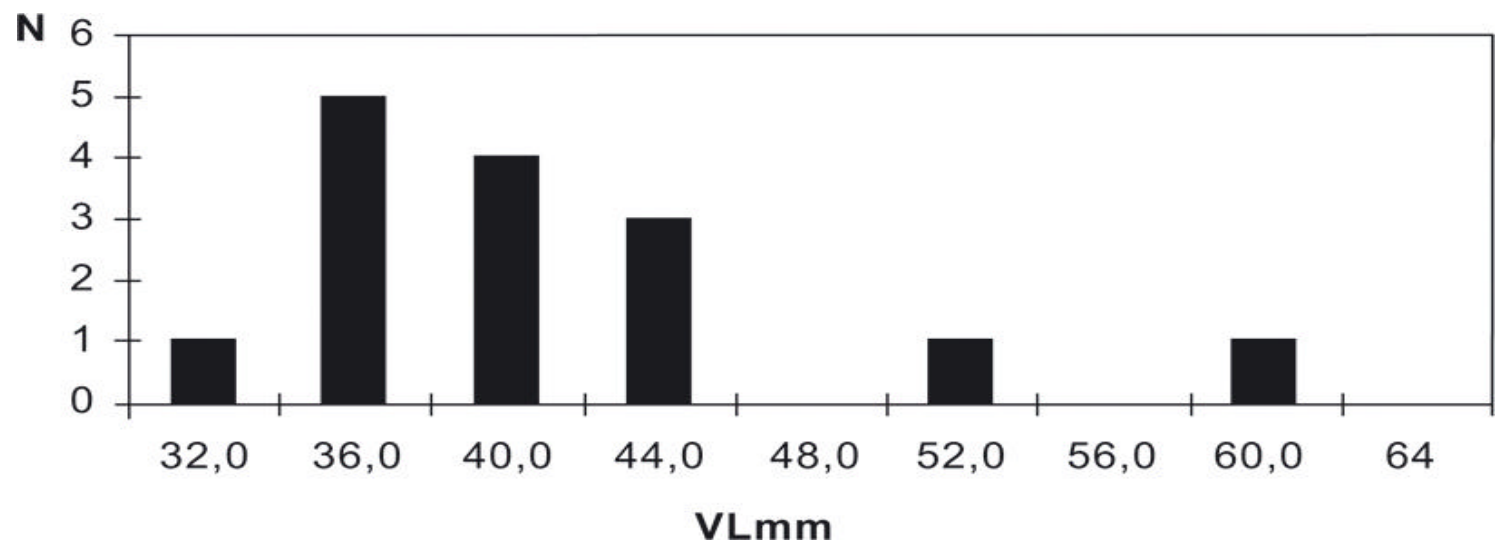

Figure 3: Size structure from the Río Grande Diplodon chilensis population.

FiguRa 3: Estructura de tamaños de la población de Diplodon chilensis de Río Grande. 
Extention of distribution range of Diplodon chilensis: PARADA, E. ET AL

\section{ACKNOWLEDGMENTS}

This work was partial supported with funds from Dirección General de Investigación, Catholic University of Temuco, Chile, Proyect 2005-4-03.

\section{BIBLIOGRAFIA}

Bonetto, A.A. 1973. Náyades de la Patagonia. Revista de la Asociación de Ciencias Naturales del Litoral 4:177-185.

HAAS, F. 1969. Superfamilia Unionacea. Das Tierreich (Berlin) Lieferung 88, Seite I-X: 1-663.

Parada, E. \& S. Peredo.1994. Un enfoque ecológico evolutivo de las estrategias de historia de vida de los hyridos chilenos (Mollusca, Bivalvia).
Boletín de la Sociedad de Biología de Concepción (Chile) 65:71-80.

Parada, E. \& S. Peredo. 2002. Estado actual de la taxonomía de bivalvos dulceacuícolas chilenos: progresos y conflictos. Revista Chilena de Historia Natural 75:691-701.

Parada, E. \& S. Peredo. 2006. Estado de conocimiento de los bivalvos dulceacuícolas de Chile. Gayana 70(1):82-87.

Parada, E., S. Peredo, G. Lara \& F. Antonín. 1989. Contribución al conocimiento de los Hyriidae chilenos. Boletín de la Sociedad de Biología de Concepción (Chile) 60:173-182.

Parada, E., S. Peredo \& C. Gallardo. 1990. Tácticas reproductivas y dinámica poblacional de Diplodon chilensis (Gray, 1828) (Bivalvia: Hyriidae). Revista Chilena de Historia Natural 63:23-35. 